\title{
Ecklonia Maxima Extract Effect in Tissue Regeneration of Symbionts at in Vivo Heteroplasmic Grafting of Some Tomatoes
}

\author{
Mădălina Doltu, Dorin Sora
}

Department of Horticultural Cultures in Protected Spaces, Research and Development Institute, for Processing and Marketing of Horticultural Products - Horting, Bucharest, Romania

\begin{abstract}
The research was conducted to determine the Ecklonia maxima extract effect in the symbiont accretion at the in vivo heteroplasmic grafting of some tomatoes. E. maxima or sea bamboo is a seaweed used for obtaining of organic extracts used as stimulators in horticulture because consists the natural plant hormones such as auxins and cytokinins which have optimal role in cell division, important activity for tissue regeneration. The experimental variants were grafted plants, combinations between different symbionts, cultivar fragments from Lycopersicon esculentum specie. The symbionts were two scions, F1 hybrids, 'Siriana' (Romanian cultivar), 'Abellus' (Dutch cultivar) and two rootstocks, 'Buzău' variety (Romanian cultivar), 'Emperador' F1 hybrid (Dutch cultivar). The algae extract used had auxins (11 $\mathrm{mg} / \mathrm{L})$ and cytokinins $(0.3 \mathrm{mg} / \mathrm{L})$. Two treatments were applied before grafting on scion and rootstock, $1 \mathrm{~mL} / 500$ $m L$ water and a treatment at grafting on soil, $5 \mathrm{~mL} / \mathrm{L}$ water. Control variant was without hormone extract. Determinations, observations and interpretations of the algae effect were made on symbionts. The best results on tissue regeneration were obtained in plants treated with sea bamboo extract compared to untreated control plants. The E. maxima extract influenced the tissue regeneration.
\end{abstract} Keywords- callusing, Lycopersicon esculentum, phytohormones, vegetative multiplication.

\section{INTRODUCTION}

Grafting has been used in agriculture for over 2000 years (Haroldesen et al., 2012) and in the horticultural industry (Rivard and Louws, 2006).

The tomato grafting has seen important developments between 2010-2015 years at Horting Institute Bucharest, Romania.

Blestos and Olympios, 2008 say that grafting of the Solanaceae is an environmentally friendly operation which reduces the incidence of crop infection by soilborne diseases and reduces the population of soil-borne pathogens in a similar way to the application of crop rotation.
Grafting can be defined as the natural or deliberate fusion of plant parts so that vascular continuity is established between them and the resulting genetically composite organism functions as a single plant (Yassin H. and Hussen S., 2015).

Pina and Errea, 2005 say they existup different reasons that may have an influence on graft success: inherent system of celular incompatibility, formation of plasmodesmata, vascular tissue connections, and the presence of growth regulators and peroxidases.

The in vitro micro-grafting technique could be solved some problems with incompatibility from scion and rootstock (Joley and Opitz, 1971; AI-Barazi and Schwabe, 1982; Sheibani and Villiers, 1995).

For Wang and Kollmann, 1996, the formation of vascular connections is considered the basic requirement for a successful graft.

Phytohormones coordinate cellular activities. E. maxima (sea bamboo) is a seaweed used for obtaining of organic extracts with hormones such as (auxins and cytokinins) which have optimal role in cell division, important activity during of the symbionts accretion at tomato grafting.

\section{MATERIALS AND METHODS}

\section{Biological material}

The experiment was conducted in 2017 , into a specialized greenhouse for production of grafted seedlings from the Department of Horticultural Cultures in Protected Spaces of the Horting Institute Bucharest.

The research has followed of the E. maxima extract effect in the symbionts accretion at in vivo heteroplasmic grafting of some tomatoes.

The experimental variants were grafted plants, combinations between different symbionts, cultivar fragments from L. esculentum specie. The symbionts were plant fragments from two scions, F1 hybrids, 'Siriana' (Romanian cultivar from the Research and Development Station for Vegetable Growing Buzău, Romania), 'Abellus' (Dutch cultivar from Rijk Zwaan company) and 
two rootstocks, 'Buzău' variety (Romanian cultivar from the Research and Development Station for Vegetable Growing Buzău, Romania), 'Emperador' F1 hybrid (Dutch cultivar from Rijk Zwaan company).

\section{Method and experimental conditions}

The obtaining of grafted watermelon seedlings has involved some steps:

- $\quad$ sowing scion and rootstock, in alveolar trays (50 $\mathrm{mL} /$ cell volume) with nutritive

substrate ( peat $_{3}:$ perlite $_{1}$ ). The peat was grain size 0-10 $\mathrm{mm}$, NPK $\left(1 \mathrm{~kg} / \mathrm{m}^{3}\right)$, microelementes: $\mathrm{B}, \mathrm{Mg}, \mathrm{Cu}, \mathrm{Mn}$, $\mathrm{Zn}, \mathrm{Fe}, \mathrm{S}\left(0.050 \mathrm{~kg} / \mathrm{m}^{3}\right)$, calcar $\left(4.7 \mathrm{~kg} / \mathrm{m}^{3}\right), \mathrm{pH} 6$ and wetting agent $100 \mathrm{ml} / \mathrm{m}^{3}$.

- $\quad$ preparation for grafting with necessary materials (clips, blades),

- in vivo heteroplasmic grafting in the phenophase of a two true leaves of the plants; manual cutting to 45 degree and splice grafting of the symbionts in silicone tube of the opposite poles, apical for scion and basal for rootstocks (Fig. 1 and Fig. 2),

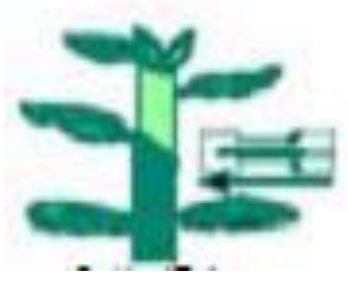

Fig. 1: Splice grafting (sursa: Lee et al., 2010 )

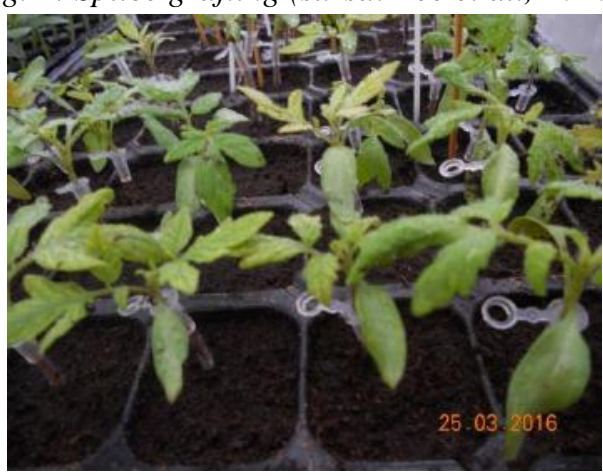

Fig. 2: Grafted tomato ('Siriana') interaction between symbionts - forming of callus in polyethylen tunnel with specific microclimate conditions (temperature of $23-25^{\circ} \mathrm{C}$ and relative air humidity of $98-100 \%$ ), for to stimulate symbionts welding

The tunnel was closed for 4 days and ventilated from $5^{\text {th }}$ day. So, it is realizing a forcing process for tissue regeneration.

- $\quad$ transferring of grafted seedlings from tunnel in the growing greenhouse.

\section{Biological treatment}

The E. maxima algae extract used had auxins $(11 \mathrm{mg} / \mathrm{L})$ and cytokins $(0.3 \mathrm{mg} / \mathrm{L})$.

Two treatments were applied before grafting, foliar on scion and rootstock, $1 \mathrm{~mL} / 500 \mathrm{~mL}$ water and a treatment at grafting, on soil, $5 \mathrm{~mL} / \mathrm{L}$ water. Control variant was without hormone extract.

A trifactorial experience was organized; the experimental factors were:

- A factor - scion: $\mathrm{a}_{1}$ - 'Siriana', $\mathrm{a}_{2}$ - 'Abellus';

- B factor - rootstock: $b_{1}$ - 'Buzău'; $b_{2}$ 'Emperador';

- C factor - treatment: $\mathrm{c}_{0}-$ without treatment, Control, $\mathrm{c}_{1}-$ with treatment.

The variants of working were: $a_{1} b_{1} c_{0}, a_{1} b_{1} c_{1}, a_{1} b_{2} c_{0}, a_{1} b_{2} c_{1}$, $a_{2} b_{1} c_{0}, a_{2} b_{1} c_{1}, a_{2} b_{2} c_{0}, a_{2} b_{2} c_{1}$.

The reception of the tomato seedlings was carried out after forcing and acclimatization, when the vascular tissues were regenerated.

\section{RESULTS}

The technological dates for obtaining of grafted tomato seedlings there are in table 1, according to Doltu et al., 2016.

Table 1: Technological dates for obtaining of Romanian grafted tomato seedlings

\begin{tabular}{|c|c|c|c|c|c|c|c|}
\hline Data & $\begin{array}{c}\text { Sowing } \\
\text { data }\end{array}$ & no. of days & $\begin{array}{c}\text { Emergence } \\
\text { data }\end{array}$ & no. of days & $\begin{array}{c}\text { Grafting } \\
\text { data }\end{array}$ & no. of days & $\begin{array}{c}\text { Callusing } \\
\text { data }\end{array}$ \\
\hline
\end{tabular}

\begin{tabular}{llllllll}
\hline Scion & February, 19 & 7 & February, 26 & 21 & March, 18 & 7 & March, 25 \\
& Fobruary, 26 & 6 & March, 3 & 15,18 & March, 18 & 7 & \\
\hline
\end{tabular}


The degree of callus forming of the grafted plants was determined using a scale ranging from 0 to 4 was used: $0=$ no callus, $1=25 \%, 2=50 \%, 3=75 \%$ and $4=100 \%$ callus formation on graft union surface (Celik, 2000), table 2.

Table.2: Results of treatment with E. maxima extract on grafted plants grade of callus development (0-4)

\begin{tabular}{|c|c|c|c|}
\hline $\begin{array}{ll}\text { Combinations } & \text { Treatment } \\
\text { (scion x rootstocks) } & \end{array}$ & $\mathrm{c}_{0}$ & $\mathrm{c}_{1}$ & $\begin{array}{c}\text { Combination } \\
\text { Average }\end{array}$ \\
\hline$a_{1} b_{1}$ & $3.3 c$ & $3.8 \boldsymbol{b}$ & $3.5 Y$ \\
\hline$a_{1} b_{2}$ & $3.2 c$ & $3.8 b$ & $3.5 Y$ \\
\hline$a_{2} b_{1}$ & $3.2 c$ & $3.8 b$ & $3.5 Y$ \\
\hline$a_{2} b_{2}$ & $3.3 c$ & $4.0 a$ & $3.7 X$ \\
\hline Treatment average & $3.2 \mathrm{~N}$ & $3.8 M$ & \\
\hline
\end{tabular}

DS5\%(ab)0.23, DS5\%(c)0.15, DS5\%(abc)0.12

The difference is insignificant when the values have the same letter.

The results of the treatment with E. maxima extract on tissue regeneration at in compatible partners are shown in Fig. 3.

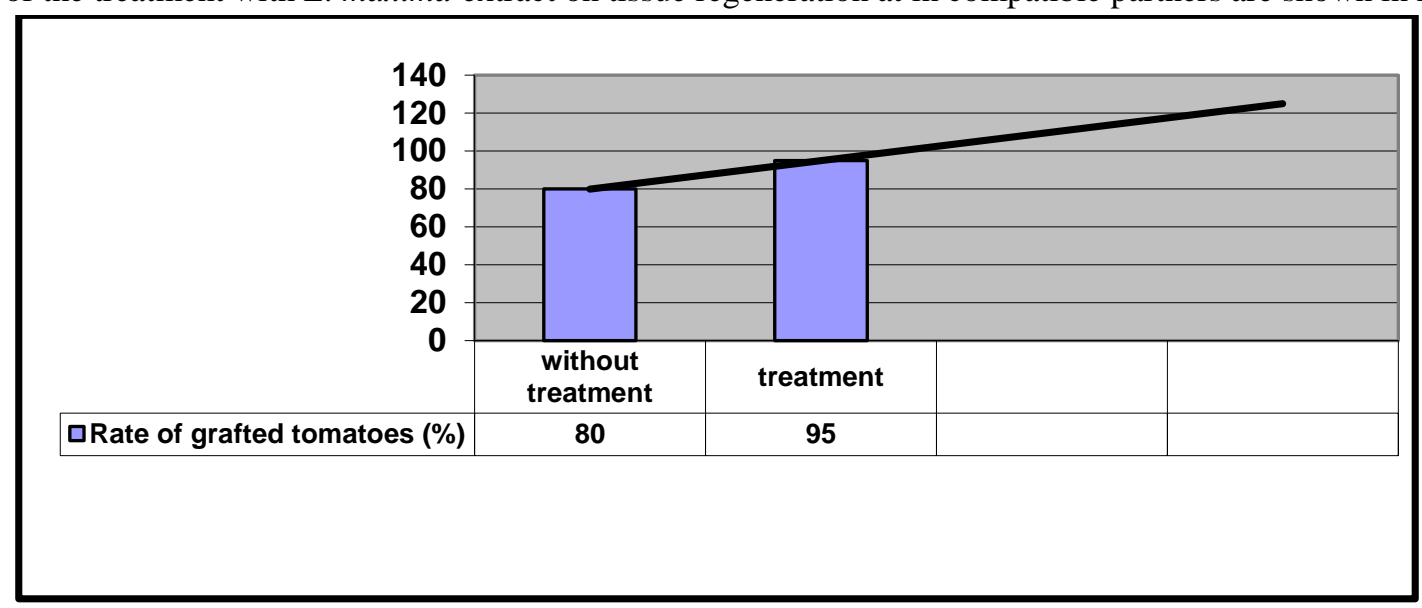

Fig. 3: Percentage of grafted tomatoes with tissue regeneration (\%)

In Fig. 3, there is a direct linear correlation between untreated and treated variants with E. maxima extract and the percentage of grafted plants with tissue regeneration. The value of the determination coefficient shows that the significance of the correlation is very significant in the case of the percentage of grafted tomatoes with tissue regeneration $\left(R^{2}=1\right)$.

95\% of the grafted plants treated with E. maxima extract were have callus, then the callus cells were determined the tissue regeneration of the compatible partners compared to untreated grafted plants, with a grafting rate of $80 \%$. Grafted plants that did not produce callus on the surface of the sections were dehydrated, the tissues oxidized, the medullary rays of the partners (scion and rootstock) were necrotic.

Several researchers have studied the influence of the $E$. maxima extract on the plant processes. E. maxima extract has bio-stimulant effect, influences some processes in plants Cipiela et al., 2016.

\section{DISCUSSION}

The tomato is a very popular and important crop in Romania. This vegetable is on the first place in greenhouse cultures from Romania; the tomato grafting has seen important developments between 2010-2015 in Romania.

The structural development of the graft union formation in tomato plants is studied in a paper together with the possible relationship with activities of peroxidases and catalases and the results suggest that increased peroxidase and catalase activities might be implicated in graft development in tomato plants (Fernandez-Garcia et al., 2004).

Plant callus is a mass of unorganized plant parenchyma cells that cover a plant wound. plant growth regulators (phytohormones), such as auxins, cytokinins, and gibberellins, initiate callus formation or somatic embryogenesis.

Nieves et al., 2004 have a study of the structural development of the graft union and the involvement of peroxidases and catalases in the process of graft formation was carried out during the first stages of the graft union 
(4, 8 and 15 days after grafting); structure of the graft union showed formation of xylem and phloem vessels through the graft union 8 days after grafting.

After 4 days from grafting, begins within by the death of cell layers at the graft interface as a wound reaction (Moore, 1984; Tiedemann, 1989).

Ramirez et al., 2012 have researched two combinations of plant growth regulators used for callus induction: $\alpha$ naphthaleneacetic acid (NAA) $5 \mathrm{mg} / \mathrm{l}$ x benzyladenine (BA) $\quad 0.1 \mathrm{mg} / \mathrm{l} \quad$ (NBA Medium) and 2,4dichlorophenoxyacetic acid (2,4-D) $1 \mathrm{mg} / \mathrm{l}$ x kinetin (Kin) $0.2 \mathrm{mg} / \mathrm{l}$ (DK Medium); the best callus yields per explant were obtained in the DK medium, the highest callus frequency $(40.0 \% ; \mathrm{p}<0.05)$ was obtained with DK medium combined with ascorbic acid.

Dan, 2008 has shown that antioxidants are able to reduce death rate, increasing the percentages of regeneration of woody plants.

\section{CONCLUSION}

Objective of this research was to analyze the effect of the E. maxima (sea bamboo) extract in tissue regeneration of the symbiots at the in vivo heteroplasmic grafting of some tomatoes.

Results obtained allow concluding that the E. maxima extract has a biostimulant effect in the symbionts accretion at the in vivo heteroplasmic grafting of the investigated tomatoes.

The best results on tissue regeneration were obtained on plants treated with sea bamboo extract compared to untreated plants, control; the significance of the correlation is very significant.

\section{ACKNOWLEDGMENTS}

This research was conducted under the Sectorial Program (ADER 2020) from Ministry of Agriculture and Rural Development Romania (2015-2018)/project no. 3.3.5/October 6, 2015, Horting Institute Bucharest is partner.

\section{REFERENCES}

[1] Al-Barazi Z., Schwabe W.W. (1982). Rooting soft wood cuttings of adult Pistaciavera. J.Hort. Sci., 57(2):247-252.

[2] Blestos F.A., Olympios C.M. (2008). Rootstocks and Grafting of Tomatoes, Peppers and Eggplants for Soil-borne Disease Resistance, Improved Yield and Quality. The European Journal of Plant Science and Biotechnology 2 (Special Issue 1):62-73.

[3] Celik H. (2000). Effects of different grafting methods applied by manual grafting units on grafting success of grapevines. Turkish Journal of Agriculture and Forestry. 24: 499-504.
[4] Ciepiela G.A., Godlewska A., Jankowska J. (2016). The effect of seaweed Ecklonia maxima extract and mineral nitrogen on fodder grass chemical composition. Environ Sci Pollut Res Int. 23(3):23017.

[5] Dan Y., 2008. Biological functions of antioxidants in plants transformation. In Vitro Cellular and Developmental Biology-Plant. 44(3):149-161.

[6] Doltu M., Sora D., Tănasă V. (2016). Obtaining of Grafted Planting Material at Some Romanian Tomatoes. Bulletin UASVM Horticulture ClujNapoca. 73(2):229-230.

[7] Fernandez-Garcia N., Carjaval M., Olmos E. (2004). Graft Union Formation in Tomato Plants: Peroxidase and Catalase Involvement. Ann Bot. 93(1):53-60.

[8] Haroldsen V.M., Szczerba M.W., Aktas H., LopezBaltazar J., Odias M.J., Chi-Ham C.L., Labavitch M.J., Bennett A.B., Powell T.L.A. (2012). Mobility of transgenic nucleic acids and proteins within grafted rootstocks for agricultural improvement. Journal Frontiers in Plant Science. 3(39):1-12.

[9] Joley, L.E., Opitz, K.W. (1971). Further experiences with propagation of Pistacia. In: Proceedings the International Plant Propagators Society Annual Meeting. 21:67-74.

[10]Lee J.M., Kubota C., Tsao S.J., Bie Z., Echevarria,P.H., Morra L, Oda M. (2010). Current status of vegetable grafting techniques, automation. Science Horticulturae. 127(2):93-105.

[11] Moore R. (1984). A model for graft compatibilityincompatibility in higher plants. American Journal of Botany. 71: 752-758.

[12] Nieves F.G., Carvajal M., Olmos E. (2004). Graft Union Formation in Tomato Plants: Peroxidase and Catalase Involvement. Annals of Botany. Oxford Academic. 93(1):53-60.

[13] Pina A., Errea P. (2005). A review of new advances in mechanism of graft compatibility-incompatibility Scientia Horticulturae. 106(1):1-11.

[14] Ramírez I., Dorta F., Cuadros-Inostroza Á., PeñaCortés H. (2012). Callus induction and plant regeneration of Ulex europaeus. Molecular Biology and Genetics. 15(4).

[15]Rivard C., Louws F. (2006). Grafting for disease resistant in herilom tomato seeds. North Carolina Cooperative Extension Service.

[16] Sheibani A., Villiers T. (1995). Effect of explant type and culture medium on micropropagation of three Pistacia species. Acta Horticulturae, 419: 229232.

[17] Tiedemann R. (1989). Graft union development and symplastic phloem contact in the heterograft 
Cucumis sativus on Cucurbita ficifolia Journal of Plant Physiology 134: 427-440.

[18] Yassin H., Hussen S. (2015). Reiview on Role of Grafting on Yield and Quality of Selected Fruit Vegetables. Global Journal of Science Frontier Research D:Agriculture and Veterinary 15(1).

[19] Wang Y., Kollmann R. (1996). Vascular differentiation in the graft union of in vitro-grafts with different compatibility. Structural and functional aspects. J. Plant Physiol. 147:521-533. 